\title{
KETERAMPILAN MEMBACA PESERTA DI KELAS 6 SDIT ENTER
}

\author{
Ana Nurhasanah ${ }^{1}$, Reksa Adya Pribadi², Susi Saraswati Binti Fatman ${ }^{3}$

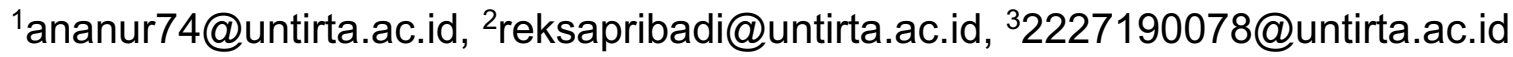 \\ 1,2,3Pendidikan Guru Sekolah Dasar Fakultas Keguruan Dan IImu Pendidikan \\ Universitas Sultan Ageng Tirtayasa
}

\begin{abstract}
Reading skill is one that must be possessed by students. The purpose of this study was to determine the reading skills of students at SDIT Enter SerangBanten. This study uses a descriptive method with a qualitative approach to data collection techniques carried out by direct observation and documentation studies. The subjects of this research are students. Based on the results of observations and research conducted by researchers, it is found that there are some students who are not fluent in reading and have not been able to determine the main idea and describe a reading text. With this problem, the researcher provides a solution by using the anti-creation guide model, group method and literacy board media with reading texts that can improve students' reading skills.
\end{abstract}

Keyword : Reading Skills

\section{ABSTRAK}

Keterampilan membaca merupakan salah satu yang harus dimiliki oleh peserta didik. Tujuan penelitian ini adalah untuk mengetahui keterampilan membaca peserta didik di SDIT Enter Serang-Banten. Penelitian ini menggunakan metode deskriptif dengan pendekatan kualitatif teknik pengumpulan data dilakukan observasi langsung dan studi dokumentasi. Subjek penelitian ini adalah peserta didik. Berdasarkan hasil observasi dan penelitian yang dilakukan oleh peneliti menghasilkan bahwa terdapat beberapa peserta didik yang belum lancar membaca dan belum mampu menentukan ide pokok serta mendeskripsikan suatu teks bacaan. Dengan adanya masalah tersebut peneliti memberikan solusi dengan menggunakan model anticiptation guide, metode berkelompok dan media papan literasi dengan teks bacaan yang dapat meningkatkan keterampilan membaca peserta didik.

Kata kunci : Keterampilan membaca

\section{A. Pendahuluan}

Pendidikan yang ideal adalah pendidikan meningkatkan belajar pada peserta didik di berbagai aspek, aspek tersebut ialah berupa kognitif, afektif 
dan psikomotorik. Seiring dengan itu selain menciptakan manusia yang memiliki akademik baik harus diimbangi dengan adanya pendidikan karakter pada peserta didik. Selain menciptakan manusia yang unggul juga menciptakan manusia yang bermoral. Hal ini didukung dengan adanya fungsi pendidikan secara nasional yang tertera pada Undang- Undang RI No.20 Tahun 2003.

Pada kurikulum Sekolah Dasar termaktub bahwa ada beberapa mata pelajaran pokok yang harus dikuasai dan dipelajari oleh peserta didik diantaranya ialah pada mata pelajaran IPA, IPS, Matematika, Bahasa Indonesia dan mata pelajaran PKn. Hal ini tertuang pada Peraturan Pemerintah RI No. 19 Tahun 2005 yang mewajibkan mata pelajaran tersebut diajarkan pada peserta jenjang Sekolah Dasar.

Bahasa Indonesia merupakan salah satu mata pelajaran yang penting dalam kurikulum pendidikan dasar. Mata pelajaran Bahasa Indonesia berperan menunjang keberhasilan peserta didik dalam mempelajari bidang studi lainnya. Hal tersebut dikarenakan dalam proses pembelajaran sebagian besar bidang studi tidak lepas dari kegiatan menyimak, berbicara, membaca dan menulis. Pentingnya peranan bahasa indonesia bagi peserta didik dijelaskan dalam Peraturan Menteri Pendidikan Nasional Nomor 22 Tahun 2006 tentang Standar Isi sebagai berikut: Bahasa memiliki peran sentral dalam perkembangan intelektual, sosial, dan emosional peserta didik dan merupakan penunjang keberhasilan dalam mempelajari semua bidang studi. Pembelajaran bahasa diharapkan membantu peserta didik mengenal dirinya, budaya orang lain, mengemukakan gagasan dan perasaan, berpartisipasi dalam masyarakat yang menggunakan bahasa tersebut, dan menemukan serta menggunakan kemampuan analitis dan imaginatif yang ada dalam dirinya.

Selain informasi yang diperoleh diatas, peneliti juga melakukan observasi terkait permasalahan yang terjadi di SDIT Enter Kota Serang khususnya pada kelas 6. Dari observasi yang dilakukan peneliti, peneliti menemukan masih banyak 
peserta didik yang memiliki hasil belajar yang kurang memuaskan. Ini dilihat dari hasil selama belajar dan pembelajaran berlangsung, ketika peserta didik mengerjakan soalsoal evaluasi disetiap pembelajaran masih terdapat nilai yang jauh dari standar.

Berdasarkan hasil observasi yang dilakukan maka dibutuhkan model, metode dan media pembelajaran yang dapat mendukung pembelajaran Bahasa Indonesia dan sebagai pemecahan masalah dari kurangnya keterampilan membaca pada peserta didik kelas 6 SDIT Enter.

Dari latar belakang diatas dapat ditarik kesimpulan bahwa terdapat permasalahan yang dialami oleh peserta didik berkaitan dengan keterampilan membaca khususnya di kelas 6 SDIT Enter sebagaimana telah dilakukan penelitian oleh peneliti, permasalahan tersebut meliputi:

1. Metode pembelajaran yang digunakan oleh guru masih bersifat satu arah atau Teacher Centered dengan guru sebagai tokoh utama dalam pembelajaran, tetapi saat ini seharusnya peserta didik yang lebih berperan aktif dalam pembelajaran.

2. Kecepatan membaca peserta didik masih tergolong lambat ketika diminta untuk membaca suatu teks bacaan, semestinya peserta didik kelas 6 Sekolah Dasar sudah mampu membaca dengan cepat dan tepat.

3. Peserta didik belum mampu menentukan letak ide pokok yang terdapat pada teks bacaan, meskipun peserta didik sebelumnya sudah mempelajari materi mengenai ide pokok dan cara menentukanya.

4. Belum mampu menentukan inti bacaan, peserta didik hanya membaca sekilas bacaan yang diberikan, sehingga ketika ditanya inti dari bacaan yang telah dibaca peserta didik belum mampu menjawab.

5. Kurang fokus dalam belajar, karena hal ini peserta didik kurang mampu menentukan ide pokok maupun inti dari bacaan yang sebelumya telah dibaca.

6. Karena beberapa permasalahan yang dialami oleh peserta didik, hasil belajar yag diperoleh peserta didik kurang memuaskan 
dan cenderung jauh dari standar yang telah ditentukan.

\section{B. Metode Penelitian}

Metode penelitian yang digunakan adalah metode penelitian deskiptif kualitatif. Dengan pengumpulan data menggunakan observasi langsung tempatnya di SDIT Enter. Yang difokuskan pada permasalahan keterampilan membaca khususnya di kelas 6 SDIT Enter.

\section{Hasil Penelitian dan}

\section{Pembahasan}

\section{Hasil Penelitian}

\section{a. Membaca dengan Lancar}

Pada hari Kamis 11 November 2021 peneliti melaksanakan observasi di SDIT-ENTER pada kelas 6 dalam penggunaan media pembelajaran papan literasi dengan teks bacaan yang berjudul Pencipta Facebook dapat dihasilkan yaitu kategori tinggi yaitu subjek 1 dan 2 . Pada subjek 1 sudah dapat membaca teks yang ada dengan lancar dan benar dalam pembacaan tanda baca seperti koma dan titik. Selanjutnya pada subjek 2 juga sudah mampu membaca teks yang disediakan dengan lancar, namun dalam pembacaan tanda baca terkadang masih salah seperti pembacaan tanda koma yang seharusnya berhenti sejenak namun subjek 2 terus saja membaca tanpa berhenti.

Pada kategori sedang yaitu subjek 3 dan 4 dapat dihasilkan bahwa subjek 3 sudah mampu membaca dengan lancar, hanya saja jika bertemu dengan kata yang sulit dibaca subjek 3 akan mengeja kata tersebut dan pada pembacaan tanda baca subjek 3 terkadang masih salah. Selanjutnya pada subjek 4 sudah dapat membaca dengan lancar hanya saja terkadang salah dalam pengejaan kata sehingga pengucapaknnya salah.

Pada kategori rendah yang terdapat subjek 5 dan 6 diperoleh hasil bahwa subjek 5 ketika diminta untuk membaca, subjek 5 ini merupakan subjek yang memiliki kekurangan khusus sehingga membaca pun masih sangat lamban sehingga membutuhkan waktu yang panjang untuk dapat membaca dan memahami isi bacaan.

Pada subjek 6 ini dalam membaca masih kurang lancar dan membutuhkan waktu cukup lama 
karena pembacaannya masih harus mengeja bacaan sehingga masih tergolong kesulitan, selain itu subjek 6 ini menjadu kurang fokus dalam belajar sehingga ketika membaca hanya sekedar membaca saja, tidak memahami isi dari teks yang dibacanya.

b. Menjelaskan pengertian sederhana

Hasil observasi penggunaan media pembelajaran papan literasi dengan teks bacaan yang berjudul Pencipta Facebook untuk mendeskripsikan suatu bacaan dapat dihasilkan bahwa kategori tinggi subjek 1 dan 2 yaitu pada subjek 1 sudah mampu mendeskripsikan kembali dengan bahasa sendiri secara baik dan tanpa adanya keraguaan, subjek 1 ini juga mendeskripsikan secara detail apa saja informasi penting yang ada pada teks bacaan. Sedangkan pada subjek 2 sudah mampu mendeskripsikan kembali dengan benar dan secara detail namum masih sedikit ragu.

Selanjutnya pada kategori sedang yaiu subjek 3 dan 4 dapat dihasilkan bahwa subjek 3 ini sudah mampu mendeskripsikan teks bacaan yang ada, namun subjek 3 tidak mendeskripsikan secara detail dan hanya mendeskripsikan bacaan yang subjek 3 ini ingat. Sama halnya dengan subjek 3 pada subjek 4 ini sudah mampu mendeskripsikan teks bacaan namun tidak secara detail dan harus diberi stimulus berulang-ulang oleh guru.

Pada kategori rendah diperoleh hasil bahwa subjek 5 di obeservasi pertama ini, diminta untuk mendeskripsikan kembali pada yang sudah bacanya, namun subjek 5 ini sedikitnya bisa mengemukakan pendapatnya walaupun 2-3 kata saja, tidak dengan mendeskripsikan dengan detail dan terperinci. Lain halnya dengan subjek 6 pada observasi pertama ketika diminta untuk mendeskripsikan secara lisan apa yang sudah dibacanya, subjek 6 ini belum mampu mendeskripsikan kembali. Guru mencoba untuk memibimbingnya namun tetap tidak bisa hanya bergantung pada jawaban gurunya saja, dengan alasan lupa dari teks yang telah dibacanya. 
c. Menjelaskan inti sebuah bacaan yang dibaca

Hasil observasi penggunaan media pembelajaran papan literasi dengan teks bacaan yang berjudul Pencipta Facebook untuk menentukan Inti paragraf dapat dihasilkan bahwa kategori tinngi subjek 1 dan 2 yaitu pada subjek 1 sudah mampu menunjukkan letak inti paragraf pada paragraf 1,2,3 dan 4 dengan benar tanpa ada keraguan, begitu juga dengan subjek 2 sudah mampu menunjukan inti paragraf dengan benar namun ada sedikit keraguan pada dirinya.

Pada kategori sedang yaitu subjek 3 dan 4 dapat dihasilkan bahwa pada subjek 3 mampu menunjukan inti paragraf namun dengan ragu-ragu dan perlu dibimbing terlebih dahulu oleh guru. Sama halnya dengan subjek 3 pada subjek 4 ini sudah bisa menunjukan inti paragraf namun perlu bimbingan terlebih dahulu oleh guru secara berulang-ulang.

Pada kategori rendah yang terdiri dari subjek 5 dan 6 diperoleh hasil bahwa subjek 5 ketika diminta untuk menunjukkan inti paragraf masih belum dapat mengetahui letak inti dari paragraf yang telah dibacanya. Subjek 5 ini masih memerlukan bimbingan yang lebih dari guru dalam membantu memahami apabila tidak dengan bimbingan guru subjek 5 ini tidak bisa menentukan suatu inti paragraf. Namun pada subjek 6 ketika diminta untuk menentukan inti paragraf belum dapat menentukan. Ketika dibimbing pun masih kesulitan untuk menentukannya karena kurangnya pemahaman dan fokus belajar subjek 6 ini.

d. Menjelaskan Ide Pokok dari suatu paragraf yang dibaca

Hasil observasi penggunaan media pembelajaran papan literasi dengan teks bacaan yang berjudul Pencipta Facebook untuk menentukan ide pokok bacaan dapat dihasilkan bahwa kategori tinngi subjek 1 dan 2 yaitu pada subjek 1 sudah mampu membacakan ide pokok pada paragraf 1,2,3 dan 4 dengan benar tanpa ada keraguan, selanjutnya subjek 2 sudah mampu membacakan ide pokok dengan benar namun hanya pada paragrag 1,2 dan 3 saja sedangkan paragraf 4 masih kurang tepat. 
Pada kategori sedang yaitu subjek 3 dan 4 dapat dihasilkan bahwa pada subjek 3 sudah mampu membacakan ide pokok paragraf 1,2,3 dan 4 dengan benar namun masih terlihat sangat ragu-ragu. Seperti halnya subjek 3 pada subjek 4 sudah mampu membacakan ide pokok pada paragraf $1,2,3$ dan 4 dengan benar namun terlihat ragu dan perlu diberikan stimulus terlebih dahulu oleh guru.

Pada kategori rendah yang terdiri atas subjek 5 dan 6 berdasarkan hasil obsrvasi pertama yang dilakukan diperoleh hasil bahwa subjek 5 ini dalam menentukan suatu ide pokok yang dibaca belum mampu menentukan dengan benar dan tepat dibutuhkan bimbingan guru dalam proses mengajar subjek 5 ini.

Tidak jauh berbeda dengan subjek 6 yang menjadi fokus penelitian ini pada observasi pertama masih ditemukan kesulitan dalam menentukan ide pokok dari suatu paragraf yang telah dibaca selain tidak membaca secara fokus subjek 6 ini juga mencari alasan lupa sehingga tidak diketahui apakah subjek 6 ini mengetahui ide pokok atau tidak. Guru mencoba membimbing dan memberikan klu pada subjek 6 namun tetap belum bisa dan mampu untuk menentukan ide pokok.

\section{Pembahasan}

Pada pembahasan ini peneliti akan menguraikan hasil penelitian dari solusi yang digunakan untuk mengurangi permasalahan pada keterampilan membaca pada kelas 6 di SDIT Enter menggunakan Model Anticipation Guide, Metode berkelompok dan Media Papan Literasi dengan teks bacaan. Hasil yang dipaparkan oleh peneliti diperoleh dari teknik observasi langsung dilapangan yang kemudian dianalisis kembali.

\section{a. Membaca dengan Lancar}

Dari beberapa kelompok yang telah peneliti bagi sebagai objek penelitian, menunjukkan bahwa dari hasil penggunaan model, media dan metode yang digunakan dalam membaca secara lancar menunjukkan peningkatan dalam keinginan untuk membaca. Terlebih pemberian waktu dalam membaca menjadikan motivasi bagi peserta didik ketika membaca walaupun masih terdapat peserta didik yang belum mampu membaca secara lancar. 
Dari penggunaan media yang digunakan peneliti, dapat menumbuhkan motivasi bagi peserta didik seperti yang dikemukakan oleh Arsyad (2013, p.29) bahwa media yang digunakan dapat memperjelas pesan dan informasi yang disampaikan serta dapat memberikan pengalaman belajar bagi peserta didik. Yang dimana dalam hal ini menumbuhkan motivasi bagi peserta didik, juga dapat mengatasi keterbatasan indera, ruang dan waktu seperti yang terjadi pada subjek peneliti.

\section{b. Menjelaskan Pengertian}

\section{Sederhana}

Dari hasil penelitian yang telah dilakukan, peneliti menganalisis hasil deskripsi yang telah dilakukan dengan memperoleh hasil bahwa kemampuan peserta didik dalam mendeskripsikan sudah cukup baik bagi beberapa subjek namun masih terdapat subjek yang belum mampu mendeksripsikan secara baik, detail dan terperinci. Dalam hal ini peneliti sudah menggunakan media, model dan metode yang sedikitnya dapat mengatasi permasalahan bagi peserta didik yang belum mampu mendeskripsikan secara baik tersebut. Karena permasalahan sebelumnya peserta didik tidak mampu mendeskripsikan, maka ini menjadi sebuah peningkatan bagi peserta didik dalam mendeskripsikan. Dengan kemauan dan minat dalam mendeskripsikan kembali menggunakan bahasa sendiri apa yang telah dibacanya kemudian hasil dari peserta didik mendeskripsikan di apresiasi dengan memajangnya di media. Hal ini dapat memberikan suatu motivasi bagi peserta didik dalam mendeskripsikan.

Dari adanya penggunaan media yang digunakan, peserta didik dapat mendeskripsikan secara lisan dan tulisan sehingga peserta didik dapat berperan aktif dalam mengemukakan pendapatnya, peserta didik juga dapat mendeskripsiskan kembali teks yang dibaca melalui sebuah teks bacaan secara sederhana menarik dan menyenangkan yang dikemukakan oleh Astriani (2017:94).

\section{c. Menjelaskan inti sebuah bacaan yang dibaca}

Peneliti memperoleh hasil bahwa masing-masing subjek dari beberapa kelompok dalam hal menjelaskan suatu inti yang dibaca 
dari penggunaan model serta media membuahkan hasil pada pembelajaran. Yaitu menghasilkan peserta didik yang responden dalam pembelajaran terutama pada saat diminta untuk menentukan inti bacaan walaupun tidak semua dapat menentukan atau menjelaskan inti bacaan yang dibaca secara tepat namun semua subjek turut aktif dalam menentukan termasuk pada subjek dengan kategori rendah dengan bimbingan guru subjek dengan kategori rendah tetap mencoba dan berusaha.

Maka dari penggunaan model serta media yang digunakan sudah memberikan dampak secara tidak langsung (sedikit demi sedikit) bagi peserta didik menjadi lebih aktif. Dalam hal menejelaskan suatu inti yang dibaca ini, peserta didik diharapkan tidak hanya membaca melainkan juga memahami bacaan yang dibacanya. Dari hasil membaca peserta didik dapat memperoleh informasi yang kemudian dapat dideskripsikan kembali inti sari dari bacaan yang dibacanya, sebagaimana yang diungkapkan oleh Widasari dalam skripsinya. d. Menjelaskan ide pokok dari suatu paragraf yang dibaca

Dari perolehan hasil observasi langsung dilaksanakan oleh peneliti peserta didik dengan subjek dari kelas 6, perihal menjelaskan ide pokok dari suatu paragraf yang dibaca tergolong cukup baik dilihat perubahan yang terjadi dari implementasi penggunaan media dan model pembelajaran serta metode. Sehingga peneliti dapat memfokuskan masing-masing subjek, dengan kata lain masing-masing subjek memiliki peningkatan yang berbeda namun masing-masing subjek memiliki perubahan. Dari perubahan yang terjadi berdasarkan hasil observasi yang dilaksanakan, memberikan dampak yang baik peserta didik menjadi lebih semangat dalam membaca serta menentukan suatu ide pokok.

Menentukan suatu ide pokok merupakan hal yang wajib bagi peserta didik ketahui dengan peserta didik mengetahui ide pokok dari suatu bacaan dengan baik dan tepat maka akan semakin mudah peserta didik dalam mengetahui apa yang dimaksud bacaan serta 
memudahkan peserta didik dalam menuliskan atau menjelaskan kembali seperti yang dikemukakan Lestari (2017:3) dalam artikel jurnalnya.

\section{Kesimpulan}

Dari hasil penelitian dan observasi yang dilakukan oleh peneliti dapat disimpulkan bahwa penggunaan model anticipation guide dengan menggunakan metode diskusi dan media papan literasi yang berisi teks bacaan cukup efektif jika diterapkan secara bertahap, dalam rangka meningkatkan kemampuan membaca peserta didik serta meningkatkan kemampuan peserta didik dalam mengidentifikasi ide pokok, inti paragraf dan mendeskripsikan suatu teks bacaan.

Hal ini dilihat dari hasil observasi yang dilakukan oleh peneliti sebanyak 2 kali, peserta didik mengalami sedikit peningkatan baik pada masingmasing subjek atau subjek 1, 2, 3, 4 , 5, dan subjek 6 , dalam hal membaca keinginan atau motivasi belajar peserta didik pun meningkat. Seperti pada subjek 3 yang sebelumnya masih mengeja saat membaca pada observasi ke dua sudah tidak mengeja ketika membaca. Bukan hanya subjek 3, subjek yang lain juga menunjukka adanya peningkatan.

Dari observasi yang dilakukan peneliti, pada observasi ke satu masih terdapat beberapa masalah terhadap peserta didik, sedangkan pada observasi ke dua yang dilakukan peneliti masalah yang terdapat pada observasi ke satu mulai teratasi, peserta didik mulai menunjukkan adanya peningkatan mengenai keterampilan membaca yag dimiliki peserta didik, dengan begitu dapat dikatakan bahwa solusi yang ditawarkan peneliti berupa penggunaan model anticipation guide, metode diskusi dan penggunaan media papan literasi dengan teks bacaan memang cocok untuk mengatasi permasalahan yang terjadi dalam hal keterampilan membaca.

Dari penggunaan model, metode, dan media pembelajaran dapat dilihat jika memberikan sedikit peningkatan bagi peserta didik dalam keterampilan membaca, tetapi tetap saja membutuhkan waktu yang sedikit panjang agar peserta didik mampu 
untuk memiliki keterampilan membaca yang baik, karena untuk menghasilkan peningkatan yang pesat pada peserta didik tidak bisa jika hanya menggunakan waktu secara singkat saja.

\section{DAFTAR PUSTAKA}

Apriliyani. Hiqmah.

(2016).

Keekfetifan

Strategi

Anticipation Guide Dalam

Pembelajaran Membaca

Pemahaman Siswa Kelas

VII SMP Negeri 2

Yogyakarta. Skripsi:

Universitas Negeri Yogyakarta.

Aryani, Suprobo, dkk. (2013).

Peningkatan Keterampilan

Membaca Pemahaman

Melalui

Strategi Know-Want-Learned

(KWL) pada siswa kelas IV

A SDN Sekaran 01

Semarang. Jurnal Pendidikan Guru

Sekolah Dasar. Vol. 1 (1). Hal.

62-70.

Lestari, Bunga. (2017). Jenis Wacana

Dalam Naskah Soal Ujian

Nasional Oleh Siswa Kelas IX

SMP Swasta Bandung

Sumatera Utara Tahun

Pembelajaran 2017/2018.

UNIMED. Hal. 1-12.
Rahman, Budi. (2014). Peningkatan Keterampilan Membaca

Perumulaan Melalui Media

Flascard Pada Siswa Kelas 1 SDN Bajayau Tengah 2. Jurnal Prima Edukasia. Vol.

2(2). Hal 127-137.

Widasari, M. Umi. (2017). Upaya Meningkatkan Kemampuan Membaca Pemahaman Siswa Melalui Metode PQ4R Pada Pelajaran Bahasa Indonesia Di Kelas IV MI Islamiyah Sumberrejo Batanghari Lampung Timur Tahun Pelajaran 2016/2017. Skripsi: Institut Agama Islam Negeri. 